\title{
Menilai Kembali Politik Hukum Perlindungan Lingkungan dalam Undang-Undang Cipta Kerja untuk Mendukung Keberlanjutan Ekologis
}

Hario Danang Pambudhi dan Ega Ramadayanti ${ }^{1}$

\begin{abstract}
Abstrak
Diundangkannya Undang-Undang Nomor 11 Tahun 2020 tentang Cipta Kerja (UU Cipta Kerja) membawa diskursus baru mengenai keberlanjutan ekologis di Indonesia. Pasalnya, terdapat perubahan politik hukum mendasar mengenai perlindungan lingkungan mengarah pada sifat eksploitatif dibandingkan konservasi sehingga menjauhi prinsip keadilan lingkungan. Hal ini dibuktikan dengan adanya permasalahan simplifikasi perizinan, disorientasi strict liability, dan pembatasan hak atas lingkungan. Padahal perlindungan lingkungan sebagai salah satu unsur keadilan lingkungan merupakan hal yang esensial sebagai upaya memastikan distribusi hak dan kualitas lingkungan hidup yang baik dan sehat bagi generasi sekarang maupun yang akan datang. Metode penelitian dilakukan melalui penelitian kualitatif dengan pendekatan yuridis normatif yang bersifat deskriptif analisis. Teknik pengumpulan data menggunakan kajian literatur dari sumber data sekunder dengan tiga bahan hukum. Hasil penelitian menyimpulkan perlu adanya suatu langkah untuk merespons perubahan politik hukum perlindungan lingkungan dalam UU Cipta Kerja agar tetap mendukung keberlanjutan ekologis, berupa arah kebijakan dalam pembangunan berkelanjutan yang lebih merefleksikan keadilan lingkungan.
\end{abstract}

Kata kunci: Ekologis, Keadilan Lingkungan, Partisipasi Publik, Politik Hukum

\begin{abstract}
Law Number 11 of 2020 on Job Creation (UU Cipta Kerja) brings a new discourse on ecological sustainability in Indonesia. Because there is a change in fundamental legal politics regarding environmental protection in an exploitative nature compared to conservation, it is moving away from environmental justice. It is evidenced by the problems of licensing simplification, strict liability disorientation, and restrictions on environmental rights. Environmental protection as one element of environmental justice becomes an essential effort to ensure the distribution of rights and quality of a good and healthy environment for generations now and in the future. This article uses qualitative research with a normative juridical approach that is descriptive analysis. Data collection techniques used are literature studies from secondary data sources with three legal materials. In conclusion, strategic measures need to be taken to respond to the political changes in environmental protection law in the UU Cipta Kerja to continue
\end{abstract}

\footnotetext{
${ }^{1}$ Penulis adalah mahasiswa Fakultas Hukum Universitas Padjadjaran.
} 
supporting ecological sustainability in the form of policy direction in sustainable development that shall reflect better environmental justice.

Keywords: Ecological, Environmental Justice, Public Participation, Legal Politics

\section{Pendahuluan}

Keberadaan Undang-Undang No- ja terdapat pengaturan yang cenderung mor 11 Tahun 2020 tentang Cipta Ker- mengancam keberlanjutan lingkungan ja (selanjutnya disebut UU Cipta Kerja) hidup. Beberapa di antaranya mengeberpengaruh besar pada sistem penata- nai: i) simplifikasi perizinan, yaitu terkait an regulasi di Indonesia. UU Cipta Kerja menggunakan konsep Omnibus Law yang merupakan bentuk penyederhanaan peraturan dengan merevisi dan mencabut beberapa undang-undang sekaligus. Konsep ini merupakan solusi dari permasalahan yang muncul karena sering terdapat tumpang tindih regulasi serta adanya fenomena over-regulation. ${ }^{2}$

Hal tersebut terjadi karena UU Cipta Kerja bertujuan untuk menciptakan lapangan kerja. Lebih lanjut, dalam konsiderans menimbang UU Cipta Kerja bahwa perlunya penyesuaian berbagai aspek aturan yang berkaitan dengan kemudahan, perlindungan dan pemberdayaan UMKM, peningkatan ekosistem investasi, percepatan proyek nasional serta peningkatan perlindungan dan kesejahteraan pekerja, menjadi urgensi dari UU Cipta Kerja. Namun, alih-alih mencapai tujuan mulianya, dalam UU Cipta Ker-

konsep izin lingkungan menjadi persetujuan lingkungan yang menghapuskan gugatan administratif lewat pengadilan jika terjadi pelanggaran; ${ }^{3}$ Kemudian ii) disorientasi strict liability yang hampir merubah definisi tanggung jawab mutlak (strict liability) menjadi liability based on fault yang berpotensi melemahkan keadilan kepada masyarakat, yang diperparah dengan iii) reduksi partisipasi masyarakat dalam pengambilan keputusan terhadap lingkungan, yaitu terbatas hanya pada masyarakat terdampak langsung. ${ }^{4}$ Maka, hal tersebut menjadikan adanya pembatasan hak atas lingkungan berkaitan dengan ketentuan yang mengatur soal penaatan dan penegakan hukum lingkungan guna memenuhi hak atas lingkungan hidup, baik secara prosedural maupun substantif. Padahal, konstitusi menjamin hak atas lingkungan hidup sebagai hal yang dijunjung ting-

\footnotetext{
${ }^{2}$ Antoni Putra, "Penerapan Omnibus Law dalam Upaya Reformasi Regulasi." Jurnal Legislasi, Vol. 17, No. 1, (2020), hlm. 2.

${ }^{3}$ Sigit Riyanto (et.al), Kertas Kebijakan Catatan Kritis terhadap UU No. 11 Tahun 2020 tentang Cipta Kerja, (Yogyakarta: Fakultas Hukum Universitas Gadjah Mada, 2020), hlm. 6.

${ }^{4}$ Ibid.
} 
gi oleh negara sesuai Pasal $28 \mathrm{H}$ ayat (1) UUD 1945. Jika isu lingkungan terus dibiarkan, dikhawatirkan akan berdampak buruk pada keberlanjutan ekologis. ${ }^{5}$

Tiga hal tersebut menunjukkan adanya penyimpangan politik hukum keadilan lingkungan yang selama ini dijadikan acuan dalam membentuk instrumen hukum yang memiliki muatan perlindungan lingkungan hidup. Adapun keadilan lingkungan adalah suatu konsep yang berbicara agar dalam mencapai tujuan kesejahteraan rakyat, kepentingan lingkungan harus tetap diperhatikan. ${ }^{6}$ Hal ini ditujukan agar pemanfaatan alam tidak eksploitatif dan kualitas lingkungan tetap terjaga, baik bagi generasi sekarang maupun generasi yang akan datang.

Berangkat dari hal tersebut, dapat terlihat bahwa diundangkannya UU Cipta Kerja membawa diskursus baru mengenai keberlanjutan ekologis di Indonesia. Pasalnya, terdapat perubahan politik hukum mendasar mengenai perlindungan lingkungan yang mengarah pada sifat eksploitatif dibandingkan dengan konservasi, sehingga hal ini menjauhi prinsip keadilan lingkungan. Untuk itu, tulisan ini berfokus pada dua identifikasi masalah, yakni: (1) Bagaimana perubahan politik hukum keadilan lingkungan dalam hal perlindungan lingkungan di UU
Cipta Kerja; dan (2) Bagaimana langkah tepat untuk merespons perubahan politik hukum keadilan lingkungan dalam hal perlindungan lingkungan di UU Cipta Kerja?

Adapun tulisan ini berpangkal dari tulisan maupun penelitian yang telah ada dan berfokus pada politik hukum lingkungan yang terus mengalami perkembangan signifikan dari sebelum tahun 1982, yakni ketika pengaturan hukum lingkungan hanya terdapat dalam satu pasal UUD 1945 dan sampai ketentuan yang dibuat pada UU Nomor 32 Tahun 2009 mengenai Perlindungan dan Pengelolaan Lingkungan Hidup (UUPPLH). Namun, berbeda dengan penelitian sebelumnya, fokus tulisan ini juga akan terbagi ke dalam arah politik hukum pembangunan berkelanjutan pasca UU Cipta Kerja demi menjamin terlaksananya pembangunan berkelanjutan. Tulisan ini akan memaparkan adanya penyimpangan oleh aturan positif yang telah merevisi UUPPLH, sehingga arah pembangunan ini harus dikembalikan pada maruahnya untuk mementingkan kepentingan ekologis dengan tetap mencapai kesejahteraan ekonomi.

Tulisan ini disajikan melalui pendekatan yuridis normatif bersifat deskriptif analisis menggunakan teknik

\footnotetext{
${ }^{5}$ Elly Kristiani Purwendah, "Merekonstruksi Ilmu Hukum ...", Prosiding Seminar Nasional Hukum dan Ilmu Sosial Ke -2, 2018, hlm. 45.

${ }^{6}$ Ibid.
} 
pengumpulan data yaitu kajian literatur dari sumber data sekunder dengan tiga bahan hukum, yaitu bahan hukum primer, sekunder dan tersier. Tulisan hukum normatif ini mencakup penelitian terhadap asas-asas hukum yang mengkaji keterkaitannya dengan doktrin hukum dan hukum positif yang berlaku. ${ }^{7}$

\section{Perkembangan Politik Hukum Keadilan Lingkungan}

Perkembangan substansi terkait lingkungan hidup dalam UUD 1945 telah menjadi diskursus dalam perkembangan muatan konstitusi di berbagai negara. Hal tersebut menunjukkan bahwa adanya suatu perkembangan bentuk politik hukum, ${ }^{8}$ untuk menambah materi lingkungan dalam konstitusi. ${ }^{9}$ Ini didasari karena adanya benturan antara kepentingan ekonomi dan kepentingan ekologis. Kepentingan ekonomi akan berbicara masalah bagaimana cara manusia untuk mencapai kesejahteraan dengan cara mengatur ketersediaan sumber daya yang bersifat terbatas untuk keper- luan hidup manusia. Dalam menjalankan cara-cara tersebut, kepentingan ekologis akan selalu menjadi yang paling merasakan dampak. Sebab, kepentingan ekologis berbicara agar kepentingan ekonomi tidak hanya menjadikan kesejahteraan sebagai tujuan utama melainkan harus memperhatikan kelestarian lingkungan dan ketersediaan sumber daya bagi kepentingan kehidupan masa kini maupun yang akan datang. ${ }^{10}$

Konteks ini sangat berkaitan dengan konsep keadilan lingkungan. Konsep keadilan lingkungan merupakan respon dari munculnya berbagai gejala tentang kerusakan alam, terutama pasca munculnya revolusi industri. Konsep ini menitikberatkan pada munculnya ketidakadilan berupa kerusakan pada kualitas lingkungan hidup sebagai akibat dari eksploitasi alam yang berlebihan. ${ }^{11}$ Konsep ini bertolak dari pandangan bahwa generasi sekarang memiliki posisi lebih kuat daripada generasi yang akan datang. Padahal generasi yang akan datang juga memiliki hak

${ }^{7}$ Soerjono Soekanto dan Sri Mamuji, Penelitian Hukum Normatif, Suatu Tinjauan Singkat, (Jakarta: Rajawali Press, 2010), hlm. 14.

${ }^{8}$ Dalam konsepsi politik hukum, Mahfud M. D. mengatakan bahwa politik hukum adalah legal policy yang telah akan atau telah dilakukan oleh pemerintah. Legal policy ini terdiri dari (1) pembangunan hukum yang berintikan pembuatan dan pembaruan terhadap materi-materi hukum agar dapat sesuai dengan kebutuhan; (2) pelaksanaan ketentuan hukum yang telah ada termasuk penegasan fungsi lembaga dan pembinaan para penegak hukum. Dari pengertian tersebut, politik hukum tidak lain mencakup proses pembuatan dan pelaksanaan hukum yang dapat menunjukkan sifat dan ke arah mana hukum dibangun dan ditegakkan.

${ }^{9}$ Hal ini terlihat dari masuknya Hak Atas Lingkungan Hidup yang Baik dan Sehat sebagai salah satu Hak Asasi Manusia. hlm. 56.

${ }^{10}$ John B. Cobb Jr., Sustainability: Economics, Ecology, and Justice, (New York: Orbis Books, 1992),

${ }^{11}$ Elly Kristiani Purwendah, Op. Cit., hlm. 44. 
yang sama untuk mendapatkan kualitas lingkungan hidup yang baik. Sebagaimana dikatakan oleh John Rawls, bahwa setiap orang pada masa kini dan masa yang akan datang memiliki klaim yang sama dan tidak dapat ditentukan pada serangkaian layanan ekosistem esensial dan non substitusi yang sepenuhnya memadai, yang kompatibel dengan serangkaian layanan yang sama untuk semuanya. ${ }^{12}$

Merujuk pada pendapat di atas, maka diperlukan suatu instrumen yang dapat mengakomodir konsep keadilan lingkungan agar dijalankan secara konsekuen oleh seluruh elemen negara. Instrumen tersebut dapat dipegang oleh hukum yang memiliki beberapa fungsi, yaitu sebagai perwujudan dari nilai-nilai tertentu, sebagai norma-norma abstrak dan alat mengatur masyarakat, serta sebagai usaha untuk mencapai tujuan-tujuan dan memenuhi kebutuhan konkret dalam masyarakat. ${ }^{13}$

Selain itu, Cobb (1992) juga berpendapat bahwa untuk menyeimbangkan kepentingan ekonomi dan kepentingan ekologis maka seharusnya ditengahi oleh pembentukan kebijakan pemerintah yang tertuang dalam suatu dokumen kebijakan. ${ }^{14}$ Berangkat dari hal tersebut, peranan hukum dan dokumen-dokumen kebijakan merupakan suatu hal yang penting untuk mengakomodir arah kebijakan pembangunan yang berlandaskan konsep keadilan lingkungan.

Lebih lanjut, di Indonesia sendiri, perhatian terhadap lingkungan hidup dapat dilacak keberadaannya dalam UUD 1945 sebagai puncak hierarki hukum tertinggi. Dalam rangkaian proses amandemen, para perumus UUD 1945 telah memasukan perhatian terhadap lingkungan dan hubungannya dengan pembangunan sebagai upaya penciptaan kesejahteraan umum. Hal tersebut dapat dilihat dalam Pasal $28 \mathrm{H}$ ayat (1) yang memproyeksikan adanya keseimbangan penjaminan kesejahteraan dengan tetap memperhatikan lingkungan hidup, ${ }^{15}$ yang tidak dapat dikorbankan akibat pelaksanaan pembangunan. Hal ini berarti bahwa pengelolaan lingkungan dan pemanfaatan sumber daya alam harus diletakkan dalam kerangka pengakuan, perlindungan, dan pemenuhan hak asasi setiap warga negara atas lingkungan hidup yang baik dan sehat.

\footnotetext{
${ }^{12}$ Ibid.

${ }^{13}$ Satjipto Rahardjo, Ilmu Hukum, (Bandung: Citra Aditya Bakti, 2006), hlm. 206.

${ }^{14}$ John B. Cobb Jr., Sustainability: Economics, Ecology, and Justice, (New York: Orbis Books, 1992), hlm. 58.

${ }^{15}$ Lihat Pasal 28H ayat (1) UUD 1945 bahwa "Setiap orang berhak hidup sejahtera lahir dan batin, bertempat tinggal, dan mendapatkan lingkungan hidup yang baik dan sehat serta berhak memperoleh pelayanan kesehatan."
} 
Tidak hanya itu, dalam pasal 33 ayat (4) UUD $1945^{16}$ juga memberikan penegasan terhadap perekonomian nasional harus didasari dengan wawasan lingkungan mengindikasikan tanggung jawab negara, bahwa negara melalui hak menguasai dapat membuat aturan-aturan dan kebijakan pemanfaatan lingkungan dan sumber daya alam guna menjamin keberlanjutan lingkungan dalam situasi pembangunan ekonomi nasional. Hal tersebut menyimpulkan bahwa UUD 1945 telah berusaha untuk menempatkan secara proporsional kepentingan lingkungan agar seimbang dengan kepentingan ekonomi. Hal ini dipertegas dengan kewajiban negara untuk mengakui, melindungi, dan memenuhi hak atas lingkungan sebagai bagian dari hak asasi manusia rakyat Indonesia.

Dalam kaitannya dengan regulasi lingkungan hidup, politik hukum keadilan lingkungan telah diakomodir dengan adanya UUPPLH. Namun, jauh sebelum itu, eksistensi penjaminan perlindungan lingkungan hidup telah diakomodir sejak diterbitkannya Undang-Undang Nomor 4 Tahun 1982 tentang Ketentuan-Ketentuan Pokok Pengelolaan Lingkungan Hidup (UU KKPPLH) yang mana politik hukum pengelolaan lingkungan mulai mengarah pada kepentingan keberlanjutan ekologi. ${ }^{17} \mathrm{Di}$ buktikan dengan adanya konsep pembangunan berwawasan lingkungan, dalam arti pembangunan dapat berlangsung dengan tidak menyebabkan kerusakan daya dukung lingkungan untuk generasi yang akan datang sebagaimana dalam pasal 3 jo. pasal 4 UU KKPPLH. Akan tetapi, UU KKPPLH masih secara sederhana mengatur ketentuan perizinan lingkungan dengan penjelasan mekanisme perizinan yang belum jelas dan baru terfokus pada izin usaha saja. ${ }^{18} \mathrm{Wa}$ laupun demikian, UU KKPPLH sebagai pengawal regulasi lingkungan di Indonesia, telah memperkenalkan konsep Analisis Mengenai Dampak Lingkungan (Amdal), ${ }^{19}$ meliputi adanya perencanaan pembangunan harus memuat perkiraan dampak terhadap lingkungan hidup sebagai dasar pertimbangan pembuatan

${ }^{16}$ Lihat Pasal 33 ayat (4) bahwa "Perekonomian nasional diselenggarakan berdasar atas demokrasi ekonomi dengan prinsip kebersamaan, efisiensi berkeadilan, berkelanjutan, berwawasan lingkungan, kemandirian, serta dengan menjaga keseimbangan kemajuan dan kesatuan ekonomi nasional."

${ }^{17}$ Muhammad Akib, "Politik Hukum Pengelolaan Lingkungan Hidup...", Thesis: Pascasarjana Undip, 2013, hlm. viii.

${ }^{18}$ Lihat Pasal 7 ayat (1) dan (2) UU No. 4 Tahun 1982 tentang Ketentuan-Ketentuan Pokok Pengelolaan Lingkungan Hidup bahwa dalam menjalankan suatu kegiatan, setiap orang wajib memelihara kelestarian dan kemampuan lingkungan dengan adanya pengeluaran izin dari instansi yang berwenang.

${ }^{19}$ Lihat Pasal 16 UU No. 4 Tahun 1982 tentang Ketentuan-Ketentuan Pokok Pengelolaan Lingkungan Hidup bahwa "Setiap rencana yang diperkirakan mempunyai dampak penting terhadap lingkungan wajib dilengkapi dengan analisis mengenai dampak lingkungan yang pelaksanaannya diatur dengan peraturan pemerintah." 
Amdal. ${ }^{20}$ Maka, terhadap UU KKPPLH pada masa itu, telah cukup mengakomodir instrumen pencegahan pencemaran dan/atau kerusakan lingkungan hidup dengan adanya mekanisme penentuan dampak untuk melaksanakan Amdal.

Kemudian arah kebijakan hukum perlindungan lingkungan kembali dipertegas melalui Undang-Undang Nomor 23 Tahun 1997 tentang Pengelolaan Lingkungan Hidup (UUPLH), dengan adanya penguatan asas dan tujuan pengelolaan dan berbagai instrumen terkait hukum lingkungan administrasi, perdata dan pidana. Dalam UUPLH, pengaturan tentang perizinan melingkupi Amdal serta izin usaha pada Pasal 18 dengan mekanisme yang cukup jelas diakomodir Pasal 19 dan Pasal 20 UUPLH. Bahkan, aturan mengenai strict liability sudah disebutkan dalam Pasal 35, yang pada penjelasan pasalnya merupakan tanggung jawab yang tidak memerlukan pembuktian terhadap unsur kesalahan oleh penggugat sebagai dasar ganti rugi dalam perkara mencemari lingkun- gan. Selain itu, pemberian akses kepada masyarakat semakin diperluas dengan adanya keharusan suatu kegiatan untuk menyampaikan informasi yang benar terutama terkait pengelolaan lingkungan, jika tidak sesuai masyarakat juga dapat mengajukan keberatan. Kemudian, adanya mekanisme pengajuan gugatan seperti class action, dan LSM pun telah diberikan hak gugat dalam misi penyelamatan lingkungan. ${ }^{21}$ Namun, perkembangan era terutama dalam masa transisi dari orde baru ke reformasi mendapati adanya kebijakan otonomi daerah dan pengaturan tata kelola pemerintahan yang baik, ${ }^{22}$ menjadi salah satu penyebab regulasi lingkungan UUPLH perlu diperbarui.

Sampai kepada tahun 2009 pengaturan lingkungan kian dilengkapi dengan frasa perlindungan dan pengelolaan lingkungan hidup yaitu pada UUPPLH. ${ }^{23}$ Dalam pengaturannya, UUPPLH secara tegas memasukkan asas-asas seperti asas tanggung jawab negara, pencemar membayar, partisipatif dan kearifan lokal, manfaat, kehati-hatian, serta tata kelola

${ }^{20}$ Lihat Penjelasan Pasal 16 UU No. 4 Tahun 1982 tentang Ketentuan-Ketentuan Pokok Pengelolaan Lingkungan Hidup bahwa “...Berdasarkan analisis ini dapat diketahui secara lebih terperinci dampak negatif dan positif yang akan timbul dari usaha atau kegiatan tersebut, sehingga sejak dini telah dapat dipersiapkan langkah untuk menanggulangi dampak negatif dan mengembangkan dampak positifnya. Dampak yang penting ditentukan antara lain oleh a. besar jumlah manusia yang akan terkena; $b$. luas wilayah penyebaran dampak; c. lamanya dampak berlangsung; $d$. intensitas dampak; e. banyaknya komponen lingkungan lainnya yang akan terkena; $f$. sifat kumulatif dampak tersebut; g. berbalik (reversible) atau tidak berbaliknya (irreversible) dampak. Pemerintah dapat membantu golongan ekonomi lemah, yang bidang usahanya diperkirakan menimbulkan dampak penting ini, untuk melaksanakan analisis mengenai dampak lingkungan."

${ }^{21}$ Lihat Pasal 37 UU No. 23 Tahun 1997 tentang Pengelolaan Lingkungan Hidup.

${ }^{22}$ Lihat Angka 7 Penjelasan Umum UU Nomor 32 Tahun 2009 tentang Perlindungan dan Pengelolaan Lingkungan Hidup.

${ }^{23}$ Dani Amran Hakim, Op. Cit., hlm. 117. 
pemerintahan yang baik dan otonomi daerah. ${ }^{24}$ Asas yang disebutkan merupakan politik hukum yang penting dalam memperjuangkan perlindungan dan pengelolaan lingkungan hidup ketika berhadapan dengan kepentingan ekonomi. Perbedaan yang paling mencolok berikutnya adalah terdapat jaminan hukum yang baik bagi orang yang memperjuangkan hak atas lingkungan dari tuntutan perdata maupun pidana. ${ }^{25}$

Selain itu, terdapat hal esensial terkait perizinan yang juga diatur dalam UUPPLH, yakni dengan memperkenalkan izin lingkungan yang menjadi dasar diterbitkannya izin usaha. Adapun untuk memiliki izin lingkungan, maka pelaku usaha perlu untuk memiliki Amdal atau UKL/UPL. ${ }^{26}$ Dari pengaturan ini, dapat dilihat bagaimana terdapat upaya untuk menjadikan izin lingkungan memiliki kedudukan yang setara dengan izin usaha. Hal ini bertujuan agar kedudukan izin lingkungan menjadi kuat, serta pertimbangan lingkungan dalam proses penyelenggaraan usaha/kegiatan menjadi pertimbangan sentral. Dapat diidentifikasikan bahwa politik hukum pengelolaan dan perlindungan lingkungan sudah diusahakan agar dapat diakomo- dir secara andal oleh UUPPLH.

Dalam UUPPLH, aspek yang menjadi sorotan perlindungan lingkungan hidup tampak dari adanya dua tahapan izin yang harus dipenuhi oleh setiap pelaku usaha/kegiatan dengan pengelolaan lingkungan hidup. Maka, setiap ada kegiatan yang diperkirakan akan berdampak (baik secara penting maupun tidak penting) pada lingkungan hidup, diwajibkan untuk memperoleh izin lingkungan terlebih dahulu. Hal ini merupakan langkah korektif dan evaluatif terhadap UUPLH tahun 1997. Dimana saat itu, setelah penilaian Amdal tidak dikenal izin lingkungan, melainkan persetujuan atas Amdal atau keputusan kelayakan lingkungan hidup yang menjadi prasyarat penerbitan izin usaha. ${ }^{27} \mathrm{Na}$ mun, hal ini tidak cukup efektif dikarenakan dalam implementasinya, tidak ada ketentuan yang menyatakan bahwa apabila terdapat suatu pelanggaran lingkungan hidup, bagaimana kaitannya dengan keberlakuan persetujuan Amdal dan izin usaha. Artinya, di antara keduanya merupakan hal yang dapat dipisahkan atau bahkan terpisah. Maka, ketika ada kegiatan/usaha yang mencemari lingkungan menyebabkan dicabutnya persetujuan

${ }^{24}$ Lihat Pasal 2 UU No. 32 Tahun 2009 tentang Perlindungan dan Pengelolaan Lingkungan Hidup.

${ }^{25}$ Lihat Pasal 66 UU No. 32 Tahun 2009 tentang Perlindungan dan Pengelolaan Lingkungan Hidup.

${ }^{26}$ Lihat Pasal 36 ayat (1) dan (2) UU No. 32 Tahun 2009 tentang Perlindungan dan Pengelolaan Lingkungan Hidup. Bahwa "setiap izin usaha dan/atau kegiatan yang wajib memiliki Amdal atau UKL-UPL wajib memiliki izin lingkungan yang diterbitkan berdasarkan keputusan kelayakan lingkungan hidup sebagaimana Pasal 31 atau rekomendasi UKL-UPL."

${ }^{27}$ Lihat Penjelasan Pasal 18 UU No. 23 Tahun 1997 tentang Pengelolaan Lingkungan Hidup. 
atas Amdal. Namun, kegiatan/usaha tersebut dapat terus berjalan karena izin usaha tidak serta merta dicabut.

Paradigma dalam politik hukum UUPPLH dimaksudkan untuk melindungi serta mengelola lingkungan hidup. Hal tersebut kian diterangkan dalam penjelasan umum UUPPLH bahwa lingkungan hidup yang baik dan sehat merupakan hak asasi dan hak institusional bagi warga negara. Maka, dalam pelaksanaan pembangunan lingkungan hidup agar berkelanjutan dan fungsi lingkungan tetap menjadi sumber penunjang hidup bagi rakyat Indonesia serta makhluk hidup lainnya. Pemerintah dan seluruh pemangku kepentingan seharusnya melakukan perlindungan dan pengelolaan terhadap lingkungan hidup yang merefleksikan konsep keadilan bagi lingkungan.

\section{Keadilan Lingkungan dalam Pe- rencanaan Pembangunan Nasional}

Selain dapat dilacak dalam kerangka regulasi yang berkaitan dengan lingkungan hidup, terdapat salah satu instrumen yang dapat merepresentasikan politik hukum keadilan lingkungan. Instrumen tersebut adalah sistem perencanaan pembangunan nasional. Hal ini sesuai dengan apa yang dikatakan Jimly Ashiddiqie, bahwa pembangunan berkelanjutan yang berwawasan lingkungan hidup dapat dirumuskan sebagai upaya sadar dan terencana yang memadukan lingkungan, termasuk sumber dayanya ke dalam proses pembangunan yang menjamin kemampuan, kesejahteraan, dan mutu hidup generasi masa sekarang dan generasi yang akan datang. ${ }^{28}$

Hal ini dimaksudkan untuk memastikan adanya keselarasan tujuan dan arah pembangunan, dimana Pemerintah diharuskan membuat rencana-rencana terpadu yang akan dilaksanakan oleh seluruh komponen bangsa demi mencapai tujuan bernegara. Rencana ini dapat diklasifikasikan dalam jangka waktu panjang (20 tahun), jangka waktu menengah (5 tahun), dan jangka waktu tahunan (1 tahun).

Rencana Pembangunan Jangka Panjang Nasional (RPJPN) Indonesia 20052025 menegaskan bahwa dalam konteks lingkungan hidup dan sumber daya alam, tujuan akhir yang hendak dicapai adalah terwujudnya kemampuan bangsa dalam pendayagunaan sumber daya alam dan perlindungan fungsi lingkungan hidup secara berkelanjutan, berkeadilan, dan berkesinambungan untuk sebesar-besarnya kesejahteraan rakyat. ${ }^{29}$

\footnotetext{
${ }^{28}$ Jimly Asshiddiqie, Green Constitution: Nuansa Hijau Undang-Undang Dasar Negara Republik Indonesia Tahun 1945, (Jakarta: Rajawali Pers, 2010), hlm. 133.

${ }^{29}$ Lihat pada Undang-Undang tentang Rencana Pembangunan Jangka Panjang Nasional 2005-2025, UU No. 17 Tahun 2007, dan LN No. 22 Tahun 2007.
} 
Tujuan tersebut diaktualisasikan melalui arah kebijakan berupa, (1) mendayagunakan sumber daya alam yang terbarukan; (2) mengelola sumber daya alam yang tidak terbarukan; (3) menjaga keamanan ketersediaan energi; (4) menjaga dan melestarikan sumber daya air; (5) mengembangkan potensi sumber daya kelautan; (6) meningkatkan nilai tambah atas pemanfaatan sumber daya alam tropis yang unik dan khas; (7) memerhatikan dan mengelola keragaman jenis sumber daya alam yang ada di setiap wilayah; (8) mitigasi bencana alam sesuai dengan kondisi geologi Indonesia; (9) mengendalikan pencemaran dan kerusakan lingkungan; (10) meningkatkan kapasitas pengelolaan sumber daya alam dan lingkungan hidup; (11) meningkatkan kesadaran masyarakat untuk mencintai lingkungan hidup. ${ }^{30}$

Hal tersebut merupakan arah dan cara bagaimana tujuan nasional dalam jangka panjang dapat tercapai dengan memerhatikan amanat UUD 1945. Untuk merelevansikan aktualisasi arah kebijakan tersebut dengan program dari periode rezim yang sedang menjabat, maka perencanaan pembangunan nasional juga mengharuskan adanya Rencana Pembangunan Jangka Menengah Nasional (RPJMN) dan Rencana Kerja Pemerintah
(RKP) yang disusun sebagai satu kesatuan untuk mewujudkan visi Indonesia sebagaimana tercantum dalam RPJPN 2005-2025.

Dalam RPJMN 2020-2024, pemerintah memiliki empat arah kebijakan dan strategi di bidang lingkungan hidup berupa: ${ }^{31}$

\section{Pencegahan Pencemaran dan Kerusakan Sumber Daya Alam dan Lingkungan Hidup}

Arah kebijakan ini diwujudkan dengan beberapa strategi seperti upaya pemantauan baik berkaitan dengan kualitas lingkungan maupun dampak dari dunia usaha; upaya pencegahan kerusakan lingkungan, baik di laut, hutan, lahan, dan lain-lain; pencegahan terhadap kerusakan komponen ekosistem; serta kerjasama yang melibatkan berbagai sektor sebagai upaya pencegahan.

\section{Penanggulangan Pencemaran dan Kerusakan Sumber Daya Alam dan Lingkungan Hidup}

Arah kebijakan ini diwujudkan dengan upaya penanganan pencemaran dan kerusakan lingkungan; pengelolaan sampah; penghapusan dan penggantian merkuri; serta pembangunan fasilitas pengelolaan limbah B3 dan medis secara terpadu.

\footnotetext{
${ }^{30}$ Ibid.

${ }^{31}$ Lihat pada Presiden Republik Indonesia, Peraturan Presiden Republik Indonesia tentang Rencana Pembangunan Jangka Menengah Nasional 2020-2024, Perpres No. 18 Tahun 2020, LN No. 10 Tahun 2020.
} 
3. Pemulihan Pencemaran dan Kerusakan Sumber Daya Alam dan Lingkungan Hidup

Arah kebijakan ini diwujudkan dengan upaya restorasi dan pemulihan gambut; pemulihan lahan bekas tambang dan lahan terkontaminasi limbah B3; pemulihan kerusakan ekosistem dan lingkungan pesisir laut; pemulihan habitat spesies terancam punah; serta peningkatan populasi spesies tumbuhan dan satwa liar terancam punah.

\section{Penguatan Kelembagaan dan Pen- egakan Hukum di Bidang Sumber Daya Alam dan Lingkungan Hidup}

Arah kebijakan ini diwujudkan dengan upaya penguatan regulasi dan kelembagaan bidang sumber daya alam dan lingkungan di pusat dan daerah; penguatan sistem perizinan, pengawasan, dan pengamanan pengelolaan sumber daya alam dan lingkungan hidup; serta penguatan mekanisme pidana, perdata, dan mediasi dalam proses penegakan hukum bidang sumber daya alam dan lingkungan hidup.

Strategi-strategi yang telah disebutkan dalam setiap arah kebijakan secara berangsur-angsur akan diwujudkan dalam RKP Pemerintah tiap tahunnya. Penyusunan RKP akan disinkronkan dengan evaluasi berjalannya RKP tahun sebelumnya serta kondisi-kondisi terbaru di lapangan.

Hal-hal sebagaimana disebutkan di atas, telah menunjukkan adanya bentuk politik hukum keadilan lingkungan di Indonesia yang tercermin dari tujuan akhir pengelolaan lingkungan di RPJPN 2005-2025 serta arah kebijakan dalam RPJMN 2020-2024. Hal selanjutnya adalah bagaimana pemerintah nantinya konsisten untuk mengejawantahkan dan menerapkan prinsip-prinsip tersebut dengan kebijakan-kebijakan dalam level yang lebih teknis.

\section{Penyimpangan Politik Hukum Keadilan Lingkungan Pasca UU Cipta Kerja}

UU Cipta Kerja disahkan pada Oktober 2020 lalu. Sayangnya, penulis mencatat justru terdapat berbagai pelemahan instrumen lingkungan hidup yang merupakan perwujudan dari penyimpangan politik hukum terkait keadilan lingkungan. Berikut adalah bahasannya:

\section{A. Simpli ikasi Perizinan}

Mengenai simplikasi perizinan ini diatur dalam UU Cipta Kerja yang mengubah nomenklatur izin lingkungan dalam UUPPLH menjadi persetujuan lingkungan yang menjadi persyaratan penerbitan perizinan berusaha. ${ }^{32} \mathrm{Hal}$ ini

\footnotetext{
${ }^{32}$ Dikatakan oleh Susiwijono selaku Sekretaris Kemenko Perekonomian, bahwa perubahan yang diusung dalam UU Cipta Kerja adalah memberikan kemudahan dalam memperoleh persetujuan lingkungan. Izin lingkungan diintegrasikan ke dalam perizinan berusaha untuk meringkas sistem per-
} 
digadang-gadang sebagai paradigma baru perizinan dalam UU Cipta Kerja untuk mengintegrasikan izin lingkungan dengan perizinan berusaha, sehingga pelaku usaha tidak perlu mengurus banyak perizinan yang sebelumnya berdiri sendiri antara satu sama lain serta jika ada pelanggaran terhadap persetujuan lingkungan, maka akan membatalkan perizinan berusaha sebagai izin utamanya. ${ }^{33}$ Namun, paradigma integrasi eksternal yang digadang-gadang dalam UU Cipta Kerja nampak tidak menunjukkan perbedaan signifikan dengan paradigma yang telah diusung dalam UUPPLH. Pasalnya, UUPPLH juga menempatkan izin lingkungan sebagai prasyarat yang harus dipenuhi sebelum diterbitkannya izin usaha. ${ }^{34}$ Sehingga, apabila izin lingkungan dicabut, maka izin usaha juga dapat dibatalkan berdasarkan UUPPLH. ${ }^{35}$
Perbedaan paradigma yang tidak terang justru menimbulkan kebingungan berkaitan dengan kedudukan persetujuan lingkungan sebagai objek sengketa tata usaha negara, mengingat UU Cipta Kerja menghapus pasal 38 dan 93 UUPPLH yang menyatakan bahwa izin lingkungan dapat dibatalkan lewat pengadilan tata usaha negara.

Padahal, apabila menilik bentuk persetujuan lingkungan yang dimaksud UU Cipta Kerja adalah Keputusan Kelayakan Lingkungan Hidup ${ }^{36}$ atau Pernyataan Kesanggupan Pengelolaan Lingkungan Hidup $^{37}$ yang telah mendapat persetujuan dari Pemerintah Pusat atau Pemerintah Daerah. Bila dikonstuksikan melalui bentuk produk persetujuan lingkungan beserta prakondisinya berdasarkan UU Cipta Kerja, maka persetujuan lingkungan memenuhi unsur untuk dapat dika-

izinan dan memperkuat penegakan hukum. Lihat lebih lanjut CNBC, "Amdal Tak Dihapus di UU Ciptaker, Hanya Disederhanakan", diakses dari Izin Amdal Tak Dihapus di UU Ciptaker, Hanya Disederhanakan (cnbcindonesia.com) pada 16 Juni 2021.

${ }^{33}$ Menurut Andri Gunawan Wibisana, fenomena semacam ini dikenal dengan sebutan integrasi eksternal, dalam arti integrasi izin usaha dengan izin lingkungan. Hal ini lazim disebut dengan izin berantai. Dalam hal ini, izin lingkungan dijadikan syarat dari izin usaha dan apabila izin lingkungan dicabut, maka izin usaha menjadi tercabut pula atau menjadi batal demi hukum. Lihat lebih lanjut dalam Andri Gunawan Wibisana, “Pengelolaan Lingkungan Melalui Izin Terintegrasi dan Berantai: Sebuah Perbandingan Atas Perizinan Lingkungan di Berbagai Negara", Jurnal Hukum \& Pembangunan, Vol. 28, No. 2, 2018, hlm. 226.

${ }^{34}$ Lihat Pasal 40 ayat 1 UU No. 32 Tahun 2009 tentang Perlindungan dan Pengelolaan Lingkungan Hidup.

${ }^{35}$ Lihat Pasal 40 ayat (2) UU No. 32 Tahun 2009 tentang Perlindungan dan Pengelolaan Lingkungan Hidup.

${ }^{36}$ Dikeluarkan oleh Menteri, Gubernur, atau Bupati/Walikota sesuai dengan kewenangannya. Lihat Pasal 49 PP 22/2021.

${ }^{37}$ Dikeluarkan oleh Menteri, Gubernur, atau Bupati/Walikota sesuai dengan kewenangannya. Lihat Pasal 62 PP 22/2021. 
takan sebagai izin sebagaimana ditegaskan pasal 39 ayat (2) Undang-Undang Nomor 30 Tahun 2014 tentang Administrasi Pemerintahan (UU Administrasi Pemerintahan) ${ }^{38}$

Selain itu, UU Cipta Kerja menggunakan pendekatan baru dengan berbasis risiko, yang membagi kategori usaha menjadi risiko rendah, menengah (terbagi menjadi menengah rendah dan menengah tinggi), dan tinggi yang akan menjadi dasar pengklasifikasian untuk memproses perizinan berusaha. Namun, perlu digaris bawahi bahwa Indonesia saat ini masih memiliki berbagai kelemahan yang seharusnya menjadi prasyarat penggunaan pendekatan berbasis risiko, yakni (1) Lemahnya basis data di Indonesia, secara menyeluruh maupun pada sektor-sektor yang ada; (2) Minimnya kajian tentang pemetaan risiko maupun implementasi kebijakan, rencana, dan program dari Pemerintah Pusat maupun Pemerintah Daerah yang berbasis pada pemetaan risiko; (3) Tingginya tingkat korupsi, dan;
(4) Ketiadaan kelengkapan inventarisasi lingkungan hidup yang berbasis pada pendekatan ekoregion dari setiap daerah secara terpadu. ${ }^{39}$ Adanya tantangan tersebut menjadi sesuatu yang harus dijawab dalam pelaksanaan UU Cipta Kerja ke depannya, apalagi pendekatan risiko lekat dengan sifat ketidakpastian, sehingga memperkirakan risiko harus bersifat dinamis dan berkelanjutan dengan mendasarkan pada pertimbangan yang penting, mendasar, rasional, dan efektif. ${ }^{40}$

Setelah berbicara paradigma baru serta tantangan persetujuan lingkungan dalam UU Cipta Kerja, berikut merupakan tabel perbandingan proses persetujuan lingkungan sebelum dan sesudah UU Cipta Kerja sebagai berikut: ${ }^{41}$

${ }^{38}$ Pasal 39 ayat (2) UU Administrasi Pemerintahan menyatakan bahwa unsur izin adalah (1) diterbitkan persetujuan sebelum kegiatan dilaksanakan; dan (2) kegiatan yang akan dilaksanakan merupakan kegiatan yang memerlukan perhatian khusus dan/atau memenuhi ketentuan peraturan perundang-undangan. Dalam hal ini, persetujuan lingkungan memenuhi prakondisi tersebut, yaitu (1) mendapat persetujuan dari Pemerintah Pusat atau Pemerintah Daerah; (2) kegiatan yang akan dilaksanakan adalah melaksanakan usaha dan/atau kegiatan yang memiliki potensi berdampak pada lingkungan hidup sebagaimana diatur dalam UU Cipta Kerja.

${ }^{39}$ Sigit (et.al), Op. Cit hlm. 37.

${ }^{40}$ Ibid.

${ }^{41}$ Anih Sri Suryani, "Perizinan Lingkungan dalam UU Cipta Kerja dan Dampaknya Terhadap Kelestarian Lingkungan", Info Singkat DPR RI, Vol. XII, No. 20/II/Puslit/Oktober 2020, hlm. 14. 


\begin{tabular}{|c|c|c|}
\hline Hal & UUPPLH & UU CK \\
\hline Tahapan & $\begin{array}{ll}\text { 1. } & \text { Proses dokumen lingkungan } \\
\text { a. } & \text { Amdal } \\
\text { b. } & \text { UKL-UPL } \\
\text { c. } & \text { SPPL } \\
\text { 2. } & \text { Keputusan Kelayakan Lingkun- } \\
\text { gan } & \text { Hidup } \\
\text { UPL atau Rekomendasi UKL- } \\
\begin{array}{ll}\text { 3. } & \text { Izin lingkungan } \\
\text { 4. } & \text { Izin usaha }\end{array}\end{array}$ & 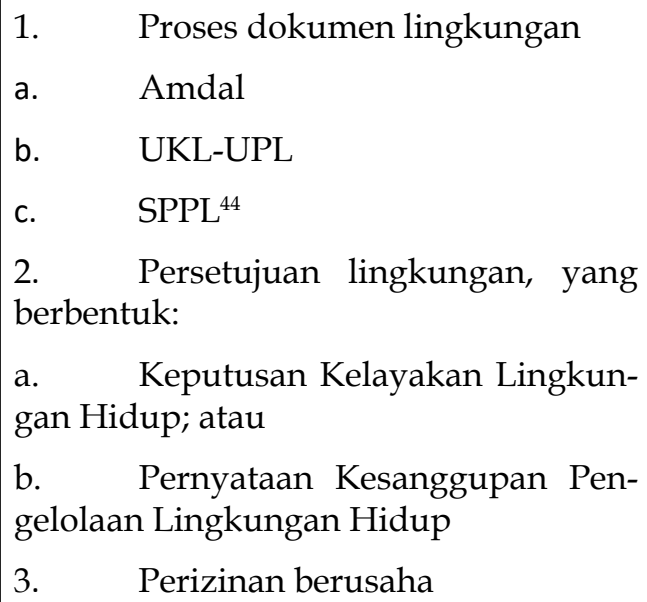 \\
\hline $\begin{array}{l}\text { Penilai Am- } \\
\text { dal }\end{array}$ & Komisi Penil & Tim Uji Kelayakan Lingkungan Hidup \\
\hline $\begin{array}{l}\text { Pembentuk } \\
\text { penilai Am- } \\
\text { dal }\end{array}$ & $\begin{array}{l}\text { Menteri, gubernur, atau b } \\
\text { ta sesuai dengan kewenar }\end{array}$ & $\begin{array}{l}\text { Lembaga Uji Kelayakan Lingkungan } \\
\text { Hidup yang dibentuk Pemerintah Pusat }\end{array}$ \\
\hline $\begin{array}{l}\text { Anggota pe- } \\
\text { nilai Amdal }\end{array}$ & $\begin{array}{l}\text { 1. Instansi lingkungan hidup dan } \\
\text { teknis terkait } \\
\text { 2. Pakar bidang lingkungan dan } \\
\text { pakar sesuai jenis kegiatan/ usaha } \\
\text { 3. Wakil masyarakat yang berpo- } \\
\text { tensi terdampak } \\
4 . \quad \text { Organisasi lingkungan hidup } \\
\text { 4. }\end{array}$ & \begin{tabular}{|ll} 
1. & Unsur pemerintah pusat \\
2. & Unsur pemerintah daerah \\
3. & Ahli bersertifikat
\end{tabular} \\
\hline $\begin{array}{l}\text { Unsur mas- } \\
\text { yarakat yang } \\
\text { dilibatkan da- } \\
\text { lam penilaian } \\
\text { Amdal }\end{array}$ & $\begin{array}{l}\text { 1. Masyarakat yang terkena } \\
\text { dampak kegiatan/ usaha } \\
\text { 2. Pemerhati lingkungan } \\
\text { 3. Masyarakat yang terpengaruh } \\
\begin{array}{l}\text { atas segala bentuk keputusan dalam } \\
\text { proses Amdal }\end{array} \\
\end{array}$ & $\begin{array}{l}\text { Masyarakat yang terkena dampak } \\
\text { langsung } 55\end{array}$ \\
\hline
\end{tabular}

${ }^{42}$ Keputusan Kelayakan Lingkungan Hidup dikeluarkan bagi usaha yang wajib Amdal untuk mendapat izin usaha, lihat lebih lanjut dalam Pasal 31 UU No. 32 Tahun 2009 tentang Perlindungan dan Pengelolaan Lingkungan Hidup.

${ }^{43}$ Rekomendasi UKL-UPL dikeluarkan bagi usaha yang wajib UKL-UPL untuk mendapat izin usaha, lihat Pasal 36 ayat (2) UU No. 32 Tahun 2009 tentang Perlindungan dan Pengelolaan Lingkungan Hidup.

${ }^{44}$ SPPL ditujukan untuk kegiatan usaha yang tidak wajib Amdal dan UKL-UPL. SPPL yang diisi pelaku usaha akan diintegrasikan ke dalam nomor induk berusaha. Sedangkan SPPL yang diisi oleh instansi pemerintah akan dijadikan sebagai dasar penerbitan persetujuan pemerintah. Lihat Pasal 65 PP 22/2021.

${ }^{45}$ Pemaknaan penilaian Amdal oleh masyarakat yang terkena dampak langsung diperluas dalam Pasal 35 PP 22/2021 dengan menyertakan pemerhati lingkungan hidup dan/atau masyarakat berkepentingan lainnya yang dapat mengajukan saran, pendapat, dan tanggapan kepada tim uji kelayakan lingkungan hidup. Hal ini jelas berbeda jika dibandingkan dengan pengaturan sebelumnya yang 


\begin{tabular}{|l|l|l|}
\hline $\begin{array}{l}\text { Bantuan dari } \\
\text { pemerintah }\end{array}$ & $\begin{array}{l}\text { Bagi usaha dan/atau kegiatan golongan } \\
\text { ekonomi lemah yang berdampak pent- } \\
\text { ing pada lingkungan hidup }\end{array}$ & $\begin{array}{l}\text { Bagi usaha dan/atau kegiatan Usaha } \\
\text { Mikro dan Kecil yang berdampak pent- } \\
\text { ing pada lingkungan hidup }\end{array}$ \\
\hline $\begin{array}{l}\text { Jika terjadi } \\
\text { pelanggaran } \\
\text { lingkungan }\end{array}$ & Konsekuensi terhadap izin lingkungan & $\begin{array}{l}\text { Konsekuensi terhadap perizinan beru- } \\
\text { saha }\end{array}$ \\
\hline
\end{tabular}

Tabel 11. Perbandingan UUPPLH dan UU Cipta Kerja

\section{B. Disorientasi Strict Liability}

UU Cipta Kerja mengubah definisi strict liability $^{46}$ dalam pasal 88 UUPPLH, dimana terdapat perubahan pasal yang semula " ...bertanggung jawab mutlak atas kerugian yang terjadi tanpa perlu pembuktian unsur kesalahan" menjadi " ...bertanggung jawab mutlak atas kerugian yang terjadi dari usaha dan/atau kegiatannya". Namun, perubahan tersebut tidak mengganti pemaknaan dari strict liability menjadi liability based on fault.

Sayangnya, pergeseran makna strict liability dapat dilihat pada Peraturan Pemerintah Nomor 22 Tahun 2021 tentang Penyelenggaraan Perlindungan dan Pengelolaan Lingkungan Hidup (PP 22/2021). Dimana dalam Pasal 501 ayat (1) jo. Pasal 500 ayat (3) PP 22/2021 men- yatakan bahwa pembuktian pertanggungjawaban mutlak merupakan bagian dari penegakan hukum perdata yang dilakukan apabila hasil kesimpulan laporan hasil pengawasan pejabat pengawas lingkungan hidup menyatakan pelaku usaha tersebut tidak taat. Hal ini tentu tidak sejalan dengan prinsip strict liability sebagai bagian dari liability based on fault. Hal ini karena dalam PP 22/2021 justru mengindikasikan strict liability hanya dapat dilakukan jika pengawasan sudah menemukan adanya ketidaktaatan, yang mana berarti perlu ada pembuktian unsur kesalahan. Hal ini tentunya merupakan disorientasi terhadap pemaknaan strict liability.

menempatkan masyarakat sebagai salah satu unsur penilai di Komisi Penilai Amdal, sehingga mereka memiliki andil dalam menentukan keputusan diterima atau tidaknya Amdal yang diajukan. Lihat Pasal 30 ayat (1) UU PPLH jo Pasal 29 PP 27/2012.

${ }^{46}$ Menurut Mochtar Koesoemaatmadja, doktrin strict liability adalah suatu tanggung jawab yang memandang kesalahan sebagai sesuatu yang tidak relevan mutlak dipermasalahkan apakah pada kenyataannya ada atau tidak. Doktrin ini diimplementasikan apabila terdapat suatu kegiatan yang memiliki klasifikasi, yaitu mengandung risiko berbahaya yang tinggi terhadap manusia, tanah, atau benda bergerak lainnya; kemungkinan terjadinya bahaya sangat besar; ketidakmampuan meniadakan risiko; kegiatan tersebut bukanlah kegiatan yang lazim dilakukan; ketidaksesuaian antara sifat kegiatan yang bersangkutan dengan lingkungan atau tempat dimana kegiatan tersebut dilakukan, dan; manfaat kegiatan tersebut bagi masyarakat dikalahkan oleh sifat-sifatnya yang berbahaya. Lebih lanjut dalam Ridho Kurniawan dan Siti Nurul Intan, "Pertanggungjawaban Pidana Korporasi ...", Jurnal Yuridis, Vol. 1, No. 2, Desember 2014., hlm. 160. Bandingkan dengan Imamulhadi, "Perkembangan Prinsip Strict Liability dan Precautionary ...," Jurnal Mimbar Hukum, Vol. 25, No. 3 (Oktober 2013), hlm. 420. 


\section{Pembatasan Hak atas Lingkungan}

Hak atas lingkungan hidup bukanlah hak yang berdiri sendiri, melainkan terdapat hak-hak turunan yang akan menentukan sejauh mana kualitas hak atas lingkungan dapat terpenuhi. ${ }^{47}$ Terdapat dua aspek yang membentuk hak atas lingkungan, yakni aspek prosedural dan aspek substantif. Aspek prosedural berkaitan dengan hak atas informasi, hak untuk berpartisipasi dalam pengambilan keputusan dan hak untuk mendapat akses keadilan. ${ }^{48}$ Sementara aspek substantif berkaitan dengan hak untuk hidup, hak untuk mendapatkan standar hidup yang layak dan sehat, serta hak untuk mendapat keadilan intra dan antar generasi. ${ }^{49}$ Terdapat beberapa ketentuan dalam UU Cipta Kerja yang justru membatasi hak atas lingkungan tersebut, khususnya dari aspek prosedural, yaitu:

\section{Pengurangan derajat partisipasi masyarakat dalam proses Amdal}

Terdapat perubahan pada pasal 26 ayat (3) UUPPLH $^{50}$ yang mempersempit makna masyarakat yang dilibatkan dalam penyusunan Amdal di UU Cipta Kerja menjadi hanya masyarakat yang terkena dampak langsung saja. ${ }^{51}$ Kendati demikian, pemaknaan terkait masyarakat terdampak langsung diperluas oleh PP 22/2021. Dalam tahap penyusunan Amdal pasca UU Cipta Kerja, misalnya. Organisasi lingkungan hidup yang telah mendampingi dan membina masyarakat terdampak langsung dianggap sebagai bagian dari masyarakat terdampak langsung pula. ${ }^{2}$ Dalam hal ini, mereka dapat mengajukan saran, pendapat, dan tanggapan (SPT) secara langsung setelah pengumuman rencana usaha dan/atau kegiatan $^{53}$ dan akan dilibatkan pada saat pelaksanaan konsultasi publik. ${ }^{54}$

${ }^{47}$ Ashabul Kahpi, “Jaminan Konstitusional Terhadap Hak Atas Lingkungan Hidup di Indonesia," Jurnal Al-Daulah, Vol. 2, No. 2, Desember 2013, hlm. 149.

${ }^{48}$ Ibid.

${ }^{49}$ Ibid.

${ }^{50}$ Pasal 26 ayat (3) UU Nomor 32 Tahun 2009 tentang Perlindungan dan Pengelolaan Lingkungan Hidup menyebutkan "Masyarakat yang terlibat dalam proses penyusunan Amdal antara lain masyarakat yang terkena dampak langsung, pemerhati lingkungan hidup, dan pihak yang terpengaruh atas segala bentuk atas segala bentuk keputusan dalam proses Amdal.

${ }^{51}$ Perubahan tersebut berbunyi "Penyusunan Dokumen Amdal dilakukan dengan melibatkan masyarakat yang terkena dampak langsung terhadap rencana usaha dan/atau kegiatan."

52 Pasal 29 PP 22/2021 telah memperjelas dan memperluas makna masyarakat yang terkena dampak langsung merupakan masyarakat yang berada di dalam batas wilayah studi Amdal yang akan terkena dampak secara langsung baik positif dan/atau negatif dari adanya rencana usaha dan/atau kegiatan. Juga meliputi pemerhati lingkungan hidup, peneliti atau lembaga swadaya masyarakat pendamping yang telah membina dan/atau mendampingi masyarakat terkena dampak langsung.

${ }^{53}$ Pasal 31 ayat (2) PP 22/2021 menyebutkan bahwa penyampaian SPT pasca pengumuman rencana usaha dan/atau kegiatan paling lama 10 hari sejak pengumuman.

${ }^{54}$ Pasal 34 ayat (2) PP 22/2021 menyebutkan bahwa masyarakat yang terdampak langsung dapat 
Sayangnya catatan besar bagi organisasi lingkungan hidup dan masyarakat berkepentingan lain yang bukan termasuk kategori masyarakat yang terkena dampak langsung, hanya memiliki hak untuk dapat memberikan SPT terhadap rencana usaha dan/atau kegiatan setelah diumumkan oleh Tim Uji Kelayakan Lingkungan Hidup dengan jangka waktu 10 hari. Tidak hanya itu, SPT tersebut juga akan dipilah lagi oleh Tim Uji Kelayakan Lingkungan Hidup apakah relevan atau tidak. Hal ini menjadi pertanyaan, mengingat belum adanya standar pengukuran SPT yang relevan oleh Tim Uji Kelayakan Lingkungan Hidup. ${ }^{55}$

Hal ini tentu berbeda pelibatan masyarakat dalam proses Amdal di rezim PPLH sebelumnya, dimana masyarakat-baik terkena dampak, pemerhati lingkungan, dan yang terpengaruh atas segala bentuk keputusan dalam proses Amdal-merupakan bagian yang tidak terpisahkan dalam pengikutsertaan penyusunan dokumen Amdal. ${ }^{56}$

Dalam penilaian Amdal, berbeda dengan sebelumnya dimana masyarakat dan organisasi lingkungan hidup merupakan salah satu unsur dalam Komisi Penilai Amdal yang memiliki kedudukan yang sama dengan unsur lainnya dalam menentukan layak atau tidaknya Amdal yang diajukan. ${ }^{57}$ Pasca UU Cipta Kerja, unsur masyarakat tidak termasuk dalam unsur Tim Uji Kelayakan Lingkungan Hidup. ${ }^{58}$ Sekalipun mereka tetap akan dilibatkan dalam proses penilaian Amdal. Hal ini menunjukkan perbedaan derajat partisipasi yang sebelumnya unsur masyarakat memiliki hak suara dalam pengambilan keputusan, namun sekarang hanya akan dilibatkan dalam proses penilaian dan sejauh apa suara mereka berpengaruh dalam pengambilan keputusan tidak dapat dipastikan.

\section{Penghapusan klausul pengajuan keberatan terhadap proses Amdal}

Dalam Pasal 26 ayat (4) UUPPLH sebelumnya, diatur ketentuan dimana masyarakat dapat mengajukan keberatan terhadap dokumen Amdal. Sayangnya, hal ini dihapus dalam UU Cipta Kerja, dimana telah terdapat pembatasan atas hak untuk berpartisipasi dalam pengam-

menyampaikan SPT dalam pelaksanaan konsultasi publik setelah penanggung jawab usaha dan/atau kegiatan menyampaikan informasi (1) deskripsi rencana usaha dan/atau kegiatan; (2) dampak potensial yang akan timbul dari identifikasi awal penanggung jawab usaha dan/atau kegiatan; (3) komponen lingkungan yang akan terkena dampak dari rencana usaha dan/atau kegiatan.

${ }^{55}$ Lihat Pasal 35 PP 22/2021.

${ }^{56}$ Lihat Peraturan Menteri Negara Lingkungan Hidup Republik Indonesia Nomor 17 Tahun 2012 tentang Pedoman Keterlibatan Masyarakat dalam Proses Analisis Dampak Lingkungan Hidup dan Izin Lingkungan.

${ }^{57}$ Lihat Pasal 30 UU No. 32 Tahun 2009 tentang Perlindungan dan Pengelolaan Lingkungan Hidup.

${ }^{58}$ Lihat Pasal 24 ayat (3) perubahan UU No. 32 Tahun 2009 tentang Perlindungan dan Pengelolaan Lingkungan Hidup dalam UU Cipta Kerja. 
bilan keputusan, khususnya apabila hasil Amdal nantinya merugikan masyarakat. Adapun, dalam PP 22/2021 hak untuk mengajukan keberatan terhadap proses Amdal ini juga tidak dijamin. Hal ini akan mereduksi pemenuhan hak akses masyarakat atas keadilan.

\section{Ketidakjelasan kedudukan per- setujuan lingkungan sebagai objek sengketa TUN}

Diubahnya nomenklatur izin lingkungan menjadi persetujuan lingkungan serta penghapusan Pasal 38 dan 93 UUPPLH dalam UU Cipta Kerja menyebabkan kedudukan persetujuan lingkungan dipertanyakan sebagai objek sengketa tata usaha negara oleh masyarakat umum. Namun, jika melihat konsep izin yang dikonstuksikan sebagai persetujuan berdasarkan UU Administrasi Pemerintahan, maka seharusnya persetujuan lingkungan dimaknai sebagai objek sengketa tata usaha negara.

Oleh karenanya, sudah seharusnya persetujuan lingkungan disebutkan secara tegas oleh pembentuk undang-undang sebagai objek sengketa tata usaha negara dalam UU Cipta Kerja. Hal ini ditujukan karena penerbitan persetujuan lingkungan tentunya telah menimbulkan akibat hukum. Maka, diperlukan ruang untuk dapat mengkoreksi hal tersebut. Tidak hanya itu, upaya untuk mengkoreksi keputusan terkait lingkungan hidup ha- nya melalui perizinan berusaha tentunya sudah terlampau terlambat. Mengingat, pasca Peraturan Pemerintah Nomor 24 Tahun 2018 tentang Pelayanan Perizinan Berusaha Terintegrasi Secara Elektronik (atau yang dikenal dengan PP Online Single Submission / PP OSS), bahkan mungkin saja telah ada kegiatan yang dapat dilakukan setelah izin lingkungan dengan komitmen keluar, seperti misalnya pengadaan tanah maupun perubahan luas lahan. ${ }^{59}$

\section{Mitigasi Penyimpangan Politik Hukum dalam UU Cipta Kerja}

Melihat adanya pergeseran politik hukum keadilan lingkungan dalam UU Cipta Kerja sebagai bagian dari upaya untuk meningkatkan tingkat investasi, maka terdapat potensi eksploitasi berlebihan terhadap sumber daya alam yang akan berdampak pada penurunan kualitas lingkungan hidup di Indonesia. Adanya beberapa isu krusial dalam UU Cipta Kerja beserta turunannya menunjukkan penggadaian kepentingan lingkungan terhadap kepentingan ekonomi para investor asing. Oleh karenanya, diperlukan beberapa upaya mitigasi agar keberlanjutan ekologis tidak dikorbankan untuk kepentingan investasi semata.

Berangkat dari empat aspek arah kebijakan dan strategi pembangunan di bidang lingkungan hidup yang terdapat

${ }^{59}$ Lihat Pasal 38 PP 24/2018 
dalam RPJMN 2020-2024 sebagai pengejawantahan RPJPN, yaitu pencegahan, penanggulangan, pemulihan, dan penguatan kelembagaan serta penegakan hukum. Penulis melihat bahwa empat aspek tersebut dapat dijadikan sebagai upaya mitigasi dalam perubahan politik hukum keadilan lingkungan di UU Cipta Kerja. Hal ini dikarenakan RPJPN dan RPJMN adalah bagian dari Sistem Perencanaan Pembangunan Nasional yang wajib dilaksanakan oleh unsur penyelenggara negara dan masyarakat di tingkat pusat dan daerah..$^{60}$ Sehingga nantinya pembangunan nasional dilaksanakan secara terarah dan terpadu melalui kebijakan yang tepat sasaran dan berorientasi pada pemenuhan tujuan bernegara.

Pertama, dalam konteks pencegahan, sebagaimana diketahui bahwa politik hukum UU Cipta Kerja adalah meningkatkan tingkat investasi untuk mendorong proses pembangunan, khususnya pembangunan ekonomi. Hal ini dapat dilihat dari adanya upaya pemerintah untuk menarik investor asing dengan iming-iming perizinan yang mudah. Namun, upaya tersebut pada akhirnya tidak dapat menjadi legitimasi untuk serta merta menerima semua bentuk investasi yang akan masuk ke Indonesia. Sehingga, untuk menghindari dampak-dampak negatif dari pembangunan yang berpotensi merusak lingkungan hidup, RPJMN 2020-2024 telah mengamanatkan ambang batas pembangunan berupa (1) kondisi daya dukung sumber daya alam dan daya tampung lingkungan, dan (2) kapasitas fiskal dan pendanaan pembangunan.

Kondisi daya dukung sumber daya alam dan daya tampung lingkungan dimaksudkan agar perencanaan pembangunan harus memerhatikan unsur lingkungan hidup sebagai modal utama yang menentukan keberlanjutan pembangunan. Artinya, kondisi daya dukung sumber daya alam dan daya tampung lingkungan berkedudukan sebagai "lampu merah" agar pembangunan tidak kelewat batas sampai merusak lingkungan hidup. ${ }^{61}$

Sedangkan, kapasitas fiskal dan pendanaan pembangunan dimaksudkan untuk mencari pendanaan alternatif, mengingat keterbatasan kapasitas fiskal dalam membiayai kebutuhan pembangunan sional.

${ }^{60}$ Lihat Pasal 1 angka 3 UU Nomor 24 Tahun 2004 tentang Sistem Perencanaan Pembangunan Na-

${ }^{61}$ Prakondisi daya dukung dan daya tampung lingkungan hidup yang berada di RPJMN 20202024 meliputi Tutupan Hutan Primer, Tutupan Hutan di atas Lahan Gambut, Habitat Spesies Kunci, Luas Pemukiman di Area Pesisir terdampak Perubahan Iklim; Kawasan Rawan Bencana, Ketersediaan Air, dan Ketersediaan Energi. Sementara itu, instrumen untuk mengendalikan daya dukung dan daya tampung lingkungan hidup menggunakan instrumen yang ada di UU No. 32 Tahun 2009 tentang Perlindungan dan Pengelolaan Lingkungan Hidup, meliputi instrumen pencegahan, penanggulangan, dan pemulihan. 
yang besar dan semakin beragam, sehingga memerlukan strategi pendanaan yang dapat mengoptimalkan pemanfaatan seluruh kapasitas pendanaan. Salah satu hal yang menjadi fokus dalam RPJMN 2020-2024 untuk pendanaan alternatif adalah dengan melakukan investasi publik yang berkualitas, dengan kriteria berupa (1) tepat sasaran dan waktu; (2) memberikan dampak positif yang signifikan dan berkelanjutan; (3) konsisten dengan arah kebijakan, program, dan rencana pembangunan, dan; (4) penggunaan sumber daya dan dana yang efisien. ${ }^{62}$

Kedua batasan tersebut dapat dikonstuksikan sebagai kerangka pengaman atau safeguards systems ${ }^{63}$ yang akan memastikan proses pembangunan yang memerhatikan keseimbangan kepentingan lingkungan dan kepentingan ekonomi. Dimana instrumen tersebut merupakan kebijakan yang ditujukan untuk mengidentifikasi kemudian menghindari, memitigasi, dan meminimalisir dampak suatu proyek pembangunan terhadap aspek lingkungan dan sosial. ${ }^{64}$ Kerangka pengaman ini pada umumnya dimiliki oleh lembaga-lembaga pendana, sehingga lembaga pendana dapat menetapkan standar jika terdapat proyek atau program yang ingin didanai, maka perlu untuk patuh atau mengikuti kerangka pengaman tersebut.

Dengan adanya instrumen tersebut, hal ini dapat membantu Pemerintah untuk memilah jenis-jenis investasi yang tidak pro kepentingan sebagai preventif measures agar dapat menyesuaikan investasi yang masuk dengan agenda pembangunan nasional yang berwawasan lingkungan. Dengan ditaatinya kedua hal tersebut, maka adanya investasi untuk mendorong proses pembangunan dimaksudkan sebagai sarana untuk memperoleh hasil (return) sekaligus mengharapkan adanya dampak positif bagi aspek sosial dan lingkungan secara persisten. ${ }^{65}$

\footnotetext{
${ }^{62}$ Presiden Republik Indonesia, Op.Cit., lihat Lampiran I, hlm. 37.

${ }^{63}$ Konsep ini telah diadopsi oleh banyak agensi pembangunan internasional, multilateral, dan bilateral sebagai kebijakan, prosedur, atau petunjuk untuk memetakan potensi risiko lingkungan dan sosial dari kegiatannya. Penamaan terhadap safeguard systems juga berbeda-beda dari tiap agensi, World Bank menyebutnya Enviromental and Social Policy, Asian Development Bank menyebutnya Safeguard Policy Statement, International Finance Corporation menyebutnya Sustainability Framework-Policy on Enviromental and Social Sustainability. Lihat lebih lanjut John Horberry, "Enviromental and Social Safeguards", Diakses dari EoD_HDYr3_12_Dec2014_Clim_Env_Safeguards.pdf (publishing.service.gov.uk) pada 9 Mei 2021.

${ }^{64}$ World Bank, "Enviromental and Social Framework, Setting Enviromental and Social Standards for Investment Project Financing", Diakses dari the esf_clean_final_for_public_disclosure_post_board_august 4.pdf (worldbank.org) pada 11 April 2021.

${ }^{65} \mathrm{Hal}$ ini merupakan gambaran bagaimana kriteria investasi yang berkualitas harus memerhatikan aspek lingkungan. Di mana dengan adanya investasi berkualitas yang tepat sasaran dan waktu akan berkaitan dengan pencapaian target pertumbuhan ekonomi Indonesia yang berwawasan lingkungan dengan menciptakan dampak positif terhadap aspek lingkungan dan sosial, yaitu tidak mengeksploi-
} 
Kedua, peluang masyarakat untuk mengajukan keberatan maupun gugatan untuk mengoreksi keputusan maupun meminta ganti rugi semestinya tetap dijamin. Seharusnya, masyarakat tetap dapat menggunakan jalur pengujian keputusan tata usaha negara melalui pengadilan tata usaha negara baik itu terhadap persetujuan lingkungan maupun perizinan berusaha. Adapun sebelum mengajukan gugatan kepada pengadilan tata usaha negara ini, warga masyarakat dapat mengajukan upaya administratif. Mekanisme ini dapat digunakan oleh warga masyarakat yang dirugikan terhadap keputusan dan/atau tindakan yang dikeluarkan oleh badan dan/atau pejabat yang berwenang dengan melakukan upaya keberatan dan banding kepada pejabat pemerintahan atau atasan pejabat yang menetapkan dan/atau mengeluarkan keputusan dan/atau tindakan sebagaimana ditegaskan dalam Pasal 75 UU Administrasi Pemerintahan. Di sisi lain, upaya hukum melalui jalur perdata juga perlu untuk tetap dijamin.

Ketiga, salah satu isu krusial dalam UU Cipta Kerja adalah penyempitan makna partisipasi masyarakat dalam proses Amdal. Isu tersebut kemudian direspon oleh pemerintah melalui PP 22/2021 yang memperluas makna partisipasi dalam proses pembentukan Amdal di tahap penyusunan sampai uji kelayakan yang dapat memberikan saran, pendapat, dan tanggapan dalam jangka waktu tertentu. ${ }^{66}$ Walaupun demikian, adanya penurunan derajat partisipasi bagi pemerhati lingkungan hidup menjadi sesuatu yang disesalkan karena tidak dibenahi dalam PP 22/2021. ${ }^{67}$

Menurut penulis, pelibatan masyarakat jangan sampai hanya pada tahap penyusunan dan penilaian Amdal sebagai bagian dari tahapan pra pemberian persetujuan lingkungan. Akan tetapi juga harus sampai pada tahap pasca pemberlakuan persetujuan lingkungan melalui desain mekanisme pengawasan yang melibatkan masyarakat. Dalam hal ini, UU Cipta Kerja menjelaskan bahwa Pemerintah Pusat dan Pemerintah Daerah melalui Menteri, Gubernur, Bupati/ Walikota wajib melaksanakan pengawasan dengan berhak untuk mendelegasikan wewenang pengawasan kepada Pejabat Pengawas Lingkungan Hidup. ${ }^{6}$ PP 22/2021 mengatur lebih lanjut sistem pengawasan yang terbagi menjadi pengawasan menjadi langsung dan tidak langsung, dimana dalam pengawasan langsung terdapat pengawasan reguler dan insidental de-

tasi sumber daya alam secara berlebihan sehingga merusak lingkungan hidup serta menciptakan kesejahteraan bagi masyarakat sesuai dengan amanat RPJMN 2020-2024.

${ }^{66}$ Lihat Pasal 28, 29, dan 35 PP 22/2021.

${ }^{67}$ Lihat Pembahasan Bab IV.

${ }^{68}$ Lihat Pasal 71 Perubahan UU PPLH dalam UU Cipta Kerja jo Pasal 491 dan 494 PP 22/2021. 
ngan menerima pengaduan dari masyarakat. ${ }^{69}$ Sistem ini seharusnya diintegrasikan dengan peran masyarakat melalui saluran pengaduan masyarakat yang akan menjadi dasar bagi Pejabat Pengawas Lingkungan Hidup untuk melakukan pemeriksaan atas dugaan pelanggaran lingkungan hidup.

Selain itu, hal ini harus ditindaklanjuti oleh pemerintah dengan membuat pedoman pengawasan yang mengejawantahkan pelibatan masyarakat, mengingat PP 22/2021 juga mengamanatkan pembentukan Peraturan Menteri yang salah satu muatannya adalah pedoman pengawasan. Dengan adanya pedoman pengawasan yang inklusif terhadap pelibatan masyarakat, hal ini akan mewujudkan arah kebijakan dan strategi penguatan kelembagaan serta penegakan hukum yang inklusif terhadap masyarakat

Keempat, hak masyarakat untuk dapat menggunakan mekanisme pengaduan dan keberatan patut untuk terus dijamin. Hal ini merupakan bentuk implementasi Pasal 65 yaitu ayat (3) dan (4) serta Pa- sal 70 UUPPLH, yang memberikan hak kepada setiap orang untuk mengajukan usul dan/atau keberatan terhadap rencana usaha yang dapat menimbulkan dampak terhadap lingkungan hidup dan mempunyai hak untuk berperan dalam perlindungan dan pengelolaan lingkungan hidup dalam mengawasi secara sosial kebijakan dan regulasi dari awal perencanaan hingga kepada pelaksanaannya.

Sampai saat ini, mekanisme pengaduan tersebut dapat merujuk kepada Peraturan Menteri Lingkungan Hidup dan Kehutanan Nomor P.22/MENLHK. SETJEN.SET. 1/3/2017 dimana diatur mengenai objek pengaduan meliputi perencanaan, pelaksanaan dan atau pasca pelaksanaan yang berpotensi menimbulkan dampak terhadap lingkungan hidup. ${ }^{70}$ Tentunya ketentuan ini perlu untuk direvisi mengikuti perkembangan hukum yang ada, yakni pasca diterbitkannya UU Cipta Kerja.

\section{Penutup}

Konsep keadilan lingkungan telah

${ }^{69}$ Lihat Pasal 498 PP 22/2021 jo Pasal 224 dan Pasal 231 PP 5/2021.

${ }^{70}$ Lihat Pasal 5 Peraturan Menteri Nomor P.22/MENLHK/SETJEN/SET. 1/3/2017 tentang Tata Cara Pengelolaan Pengaduan Dugaan Pencemaran dan/atau Perusakan Lingkungan Hidup dan/atau Perusakan Hutan. kemudian pada ayat (2) dijelaskan mengenai objek pengaduan yang dimaksud, meliputi: a. usaha dan/atau kegiatan yang tidak memiliki atau tidak sesuai dengan izin di bidang lingkungan hidup dan/atau kehutanan; b. pencemaran dan/atau perusakan lingkungan hidup; c. perusakan hutan; d. pengelolaan limbah B3 yang tidak sesuai dengan ketentuan peraturan perundang-undangan; e. pembalakan liar; f. pembakaran hutan dan lahan; g. perambahan kawasan hutan; h. perburuan, peredaran, dan perdagangan tumbuhan dan satwa liar ilegal; i. konflik tenurial kawasan hutan; j. pemanfaatan sumber daya genetik dan pengetahuan tradisional; dan/atau k. usaha dan/atau kegiatan lainnya yang bertentangan dengan ketentuan peraturan perundang-undangan di bidang lingkungan hidup, kehutanan, atau konservasi sumber daya alam hayati dan ekosistemnya. 
menjadi politik hukum yang menjiwai berbagai instrumen yang mengatur perihal lingkungan hidup di Indonesia, baik itu instrumen regulasi maupun perencanaan. Pada akhirnya, tujuan dari adanya politik hukum keadilan lingkungan adalah untuk memastikan terlaksananya pembangunan berkelanjutan yang berwawasan lingkungan di Indonesia.

UU Cipta Kerja beserta turunannya memperlihatkan pergeseran makna politik hukum keadilan lingkungan melalui isu simplifikasi perizinan, disorientasi strict liability, dan pembatasan hak atas lingkungan. Hal tersebut tidak bisa dianggap sepele agar dampak terburuk tidak terjadi pada kualitas lingkungan. Mengingat UU Cipta Kerja beserta turunannya sudah efektif berlaku sampai ada tindakan hukum yang dikeluarkan untuk membatalkannya. Hal ini menjadi refleksi besar, di mana pemerintah harus terus memupuk itikad baik dalam membangun kolaborasi bersama masyarakat untuk melaksanakan ketentuan dalam UU Cipta Kerja beserta turunannya.

Oleh karenanya, diperlukan beberapa upaya mitigasi agar pelaksanaan tersebut dapat terbingkai secara baik berupa pemerhatian batasan pembangunan sebagai safeguard system sesuai amanat RPJMN 2020-2024 yang akan memitigasi dan memperkuat upaya pencegahan dengan melakukan pemilahan jenis investasi yang akan diakomodir; adanya jaminan bagi masyarakat untuk dapat melakukan upaya hukum, baik secara administrasi maupun perdata untuk dapat mengoreksi keputusan maupun tindakan yang dirasa tidak memenuhi rasa keadilan masyarakat dan lingkungan, mendorong pelibatan masyarakat dalam desain pengawasan yang inklusif dalam muatan pedoman pengawasan pemerintah, penggunaan mekanisme pengaduan lingkungan sebagai wujud pengawasan sosial. Hal ini untuk menjamin bahwa investasi yang menjamin kemudahan usaha untuk mendorong proses pembangunan tidak serta merta "menggadaikan" kepentingan lingkungan untuk kepentingan ekonomi semata. 


\section{DAFTAR PUSTAKA}

\section{Peraturan Perundang-Undangan}

Indonesia. Undang-Undang Ketentuan-Ketentuan Pokok Pengelolaan Lingkungan Hidup, UU No. 4 Tahun 1982, LN No. 12 Tahun 1982, TLN No. 3215.

Undang-Undang Pengelolaan Lingkungan Hidup, UU No. 23 Tahun 1997, LN No. 68 Tahun 1997, TLN No. 3699.

- Undang-Undang Sistem Perencanaan Pembangunan Nasional. UU No. 24 Tahun 2004, LN No. 104 Tahun 2004, TLN No. 4421.

- Undang-Undang Perlindungan dan Pengelolaan Lingkungan Hidup, UU No. 32 Tahun 2009, LN No. 140 Tahun 2009, TLN No. 5059.

Peraturan Pemerintah Izin Lingkungan, PP No. 27 Tahun 2012, LN No. 48 Tahun 2012, TLN No. 5285.

. Undang-Undang Administrasi Pemerintahan, UU No. 30 Tahun 2014, LN. No. 292 Tahun 2014, TLN No. 5601.

. Peraturan Menteri Tata Cara Pengelolaan Pengaduan Dugaan Pencemaran dan/atau Perusakan Lingkungan Hidup dan atau Perusakan Hutan, Permen No. P.22/MENLHK/SETJEN/ SET.1/3/2017, Berita Negara Tahun 2017 No. 621.

Peraturan Pemerintah Pelayanan Perizinan Berusaha Terintegrasi Secara Elektronik, PP No. 24 Tahun 2018, LN No. 90 Tahun 2018, TLN No. 6215.
Peraturan Presiden Republik Indonesia tentang Rencana Pembangunan Jangka Menengah Nasional 2020-2024, Perpres No. 18 Tahun 2020, LN No. 10 Tahun 2020. . Undang-Undang Cipta Kerja, UU No. 11 Tahun 2020, LN No. 245 Tahun 2020, TLN No. 6573.

. Peraturan Pemerintah Penyelenggaraan Perlindungan dan Pengelolaan Lingkungan Hidup. No. 22 Tahun 2021, LN No. 32 Tahun 2021, TN No. 6634.

Buku

Asshiddiqie, Jimly. Green Constitution: Nuansa Hijau Undang-Undang Dasar Negara Republik Indonesia Tahun 1945. Jakarta: Rajawali Pers. 2010.

Cobb Jr, John B. Sustainability: Economics, Ecology, and Justice. New York: Orbis Books. 1992.

Fadli, Moh. Mukhlish dan Mustafa Lutfi. Hukum dan Kebijakan Lingkungan. Malang: UB Press. 2016.

Mahfud MD, Mohammad. Politik Hukum di Indonesia. Jakarta: LP3ES. 1998.

Priyanta, Maret dan Nadia Astriani. Buku Ajar: Hukum Lingkungan. Bandung: Kalam Media. 2015.

Rahardjo, Satjipto. Ilmu Hukum. Bandung: Citra Aditya Bakti. 2006.

Soekanto, Soerjono, dan Sri Mamuji. Penelitian Hukum Normatif, Suatu Tinjauan Singkat. Jakarta: Rajawali Press. 2010.

\section{Artikel Jurnal/Media Massa}

Akib, Muhammad. "Politik Hukum Pengelolaan Lingkungan Hidup dalam 
Perspektif Otonomi Daerah Menuju Pengaturan yang Berorientasi Keberlanjutan Ekologi", Thesis: Pascasarjana Undip, 2013.

Al-Farizy, Shallman. "Pertanggungjawaban Mutlak (Strict Liability) Dalam Hukum Perdata Lingkungan di Indonesia (Kajian UU Pengelolaan Dan Perlindungan Lingkungan Hidup)", Prosiding Seminar Nasional, 2016.

Anisah, Bintan Rahayu. “Eksistensi Investasi Hijau dalam Poros Pembangunan Ekonomi sebagai Bentuk Manifestasi Perlindungan atas Lingkungan Hidup", Padjadjaran Law Review, Vol. 8, No. 1, 2020.

Ansell, Chris., dan Alison Gash. "Collaborative Governance in Theory and Practice", Journal of Public Administration Research and Theory, Vol. 18, No. 4, 2008.

Gunawan Wibisana, Andri, "Pengelolaan Lingkungan Melalui Izin Terintegrasi dan Berantai: Sebuah Perbandingan Atas Perizinan Lingkungan di Berbagai Negara", Jurnal Hukum \& Pembangunan, Vol. 28, No. 2, 2018.

Hakim, Dani Amran. "Politik Hukum Lingkungan Hidup di Indonesia Berdasarkan Undang-Undang Nomor 32 Tahun 2009 tentang Perlindungan dan Pengelolaan Lingkungan Hidup," Fiat Justisia Jurnal Ilmu Hukum, Vol. 9, No. 2, April-Juni 2015.

Imamulhadi, "Perkembangan Prinsip Strict Liability dan Precautionary dalam Penyelesaian Sengketa Lingkungan Hidup di Pengadilan," Jurnal Mimbar
Hukum, Vol. 25, No. 3, Oktober 2013.

Kahpi, Ashabul. “Jaminan Konstitusional Terhadap Hak Atas Lingkungan Hidup di Indonesia," Jurnal Al-Daulah, Vol. 2, No. 2, Desember 2013.

Kurniawan, Ridho dan Siti Nurul Intan, "Pertanggungjawaban Pidana Korporasi Berdasarkan Asas Strict Liability," Jurnal Yuridis, Vol. 1, No. 2, Desember 2014.

Mutalib, Muhammad Thabrani. "Kewenangan Pengadilan Menguji Norma Peraturan Kebijakan (Beleidsregel)," Thesis: Pascasarjana UII, 2017.

Purwendah, Elly Kristiani. "Konstitusionalisasi Keadilan Lingkungan di Indonesia sebagai Keadilan Eko-Sosial berciri Ekosentrisme," Prosiding Seminar Nasional Hukum dan Ilmu Sosial Ke-2, 2018.

Putra, Antoni. "Penerapan Omnibus Law dalam Upaya Reformasi Regulasi." Jurnal Legislasi Vol. 17, No. 1, 2020.

Riyanto, Sigit (et.al). “Kertas Kebijakan Catatan Kritis terhadap UU No. 11 Tahun 2020 tentang Cipta Kerja," Yogyakarta: Fakultas Hukum Universitas Gadjah Mada, 2020.

Suryani, Anih Sri. "Perizinan Lingkungan dalam UU Cipta Kerja dan Dampaknya Terhadap Kelestarian Lingkungan", Info Singkat DPR RI, Vol. XII, No. 20/II/Puslit, Oktober 2020.

Wibisana, Andri Gunawan. “Pengelolaan Lingkungan Melalui Izin Terintegrasi dan Berantai: Sebuah Perbandingan Atas Perizinan Lingkungan di Berba- 
gai Negara", Jurnal Hukum \& Pembangunan, Vol. 28, No. 2, 2018.

\section{Lain-lain}

CNBC Indonesia, “Izin Amdal Tak Dihapus di UU Ciptaker, Hanya Disederhanakan", diakses dari https://www.cnbcindonesia.com/ news/20201009141011-4-193171/ izin-amdal-tak-dihapus-di-uu-ciptaker-hanya-disederhanakan pada 16 Juni 2021.

Horberry, John. "Enviromental and Social Safeguards", Diakses dari EoD HDYr3 12 Dec2014 Clim Env Safeguards.pdf (publishing.service.gov. uk) Pada 9 Mei 2021.

Matriks Analisis Rancangan Undang-Undang Cipta Kerja dalam Naskah Akademik RUU Cipta Kerja, diakses dari Naskah Akademis RUU Tentang Cipta Kerja - Portal Resmi UU Cipta Kerja - Informasi Seputar UU Cipta Kerja (uu-ciptakerja.go.id).

Nursadi, Harsanto . "Pengaturan Baru Lingkungan Pada UU CK", diakses dari Webinar "Pengaturan Lingkungan Hidup dalam Undang-Undang Nomor 11 Tahun 2020 tentang Cipta Kerja" - YouTube pada 7 Mei 2021. Horberry, John. "Enviromental and Social Safeguards", diakses dari EoD HDYr3_12_Dec2014_Clim_Env_Safeguards.pdf (publishing.service.gov. uk) Pada 9 Mei 2021.

World Bank, "Enviromental and Social Framework, Setting Enviromental and Social Standards for Investment Project Financing", the_esf_clean_fi- nal_for_public_disclosure_post_board_august_4.pdf (worldbank.org) diakses tanggal 11 April 2021. 